\title{
Effect of Angiotensin II and Losartan on the Phagocytic Activity of Peritoneal Macrophages from Balb/C Mice
}

\author{
Paula Belline, Patrícia da Silva Melo*, Marcela Haun*, Fernanda Boucault Palhares, \\ Patrícia Aline Boer, José Antônio Rocha Gontijo/ ${ }^{+}$, José Francisco Figueiredo
}

Disciplinas de Nefrologia e Medicina Interna, Núcleo de Medicina e Cirurgia Experimental, Departamento de Clínica Médica, Faculdade de Ciências Médicas *Departamento de Bioquímica, Instituto de Biologia, Universidade Estadual de Campinas,

13083-970 Campinas, SP, Brasil

Angiotensin II (AII), a product of rennin-angiotensin system, exerts an important role on the function of immune system cells. In this study, the effect of AII on the phagocytic activity of mouse peritoneal macrophages was assessed. Mice peritoneal macrophages were cultured for $48 \mathrm{~h}$ and the influence of different concentrations of AII $\left(10^{-14}\right.$ to $10^{-7} \mathrm{M}$ ) and/or losartan, $10^{-16}$ to $10^{-6} \mathrm{M}$ ), an $A T_{1}$ angiotensin receptor antagonist, on phagocytic activity and superoxide anion production was determined. Dimethylthiazoldiphenyltetrazolium bromide reduction and the nucleic acid content were used to assess the cytotoxicity of losartan. A stimulatory effect on phagocytic activity $(P<0.05)$ was observed with $10^{-13} \mathrm{M}$ and $10^{-12} \mathrm{M}$ AII concentrations. The addition of losartan (up to $10^{-14} \mathrm{M}$ ) to the cell cultures blocked $(P<0.001)$ the phagocytosis indicating the involvement of $A T_{1}$ receptors. In contrast, superoxide anion production was not affected by AII or losartan. The existence of $A T_{1}$ and $A T_{2}$ receptors in peritoneal macrophages was demonstrated by immunofluorescence microscopy. These results support the hypothesis that AII receptors can modulate murine macrophage activity and phagocytosis, and suggest that AII may have a therapeutic role as an immunomodulatory agent in modifying the host resistance to infection.

Key words: angiotensin receptor - cytotoxicity peritoneal macrophage - phagocytosis

In recent years, much insight has been gained in the biochemical pathways by which angiotensin II (AII) exerts its effects on cells. In particular, the cloning of the A II receptors $\mathrm{AT}_{1 \mathrm{~A}}, \mathrm{AT}_{1 \mathrm{~B}}$, and $\mathrm{AT}_{2}$ has led to better understanding of how AII interacts with different cells to produce its physiological responses (Regitz-Zagrosek et al. 1996, Lavoie \& Sigmund 2003).

The renin-angiotensin system (RAS) is an important regulatory mechanism for cardiovascular homeostasis in normal and hypertensive subjects (Brewster et al. 2003, Lavoie \& Sigmund 2003). Previous reports have shown that macrophages from different tissues express components of the RAS (Nickening et al. 1997, Lamparter et al. 1998) and granuloma macrophages can synthesize angiotensin (Weinstock \& Blum 1987). In addition, high levels of renin mRNA are expressed by monocytes and macrophages in the necrotic myocardium (Iwai et al. 1996). The ability of AII to stimulate cardiac fibroblast proliferation and extracellular matrix (ECM) synthesis by these cells suggests an important role for AII in ventricular remodeling. This conclusion agrees with the demonstration that AII can influence the accumulation of ECM and the synthesis of type I collagen, fibronectin, biglycan, and growth factors (Wolf et al. 1992, Matisusaka \& Ichikawa 1997).

Financial support: CNPq (500868/91-3), Fapesp (00/122168), and Capes

${ }^{+}$Corresponding author. Fax: +55-19-3788.8924. E-mail: figueiredojf@fcm.unicamp.br

Received 22 September 2003

Accepted 16 January 2004
The presence of specific AII binding sites in macrophages has been suggested by several studies (Dezso \& Fóris 1981, Thomas \& Hoffman 1984, Dezso et al. 1988). Prabha et al. (1990) were the first to show that at physiological concentrations, AII can increase free-radical generation by polymorphonuclear neutrophils. Kumar and Das (1993) subsequently confirmed this observation. Hydrogen peroxide, peroxide, and superoxide production via $\mathrm{AT}_{1}$ receptors is an important component in the respiratory burst response that can be used to measure the activation of macrophages (Scheidegger et al. 1997, Jaimes et al. 1998, Pueyo et al. 1998, Yanagitani et al. 1999).

Based on these reports, this study was designed to investigate the role of $\mathrm{AT}_{1}$ receptors in the phagocytic activity and superoxide release of mouse peritoneal macrophages. The effect of AII on these cells was determined in the absence and presence of losartan, an $\mathrm{AT}_{1}$ receptor antagonist. We also evaluated the cytotoxic effect of losartan and the presence of $\mathrm{AT}_{1}$ and $\mathrm{AT}_{2}$ receptors on peritoneal macrophages.

\section{MATERIALS AND METHODS}

Cultures of macrophages - Male Balb/C mice 6-8 weeks old were supplied by the Central Animal House (Unicamp). The experimental protocols described here were approved by the institutional Committee for Ethics in Animal Experimentation. Macrophages were harvested from the peritoneal cavities of mice and were resuspended in Hanks' balanced salt solution (HBSS) (Sigma Chemical Co., St. Louis, MO). The number of viable cells was determined by trypan blue dye exclusion. The resuspended macrophages $\left(2 \times 10^{5}\right.$ cells/well) were allowed to adhere to round $13 \mathrm{~mm}$ glass coverslips placed in 24-well plates (Corning 
Inst., NY, US). Non adherent cells were removed by rising the coverslips with HBSS and the adherent cells were incubated in $1 \mathrm{ml}$ of Roswell Park Memorial Institute (RPMI1640) medium (Sigma) supplements with $10 \%$ fetal bovine serum at $37^{\circ} \mathrm{C}$ in a $5 \% \mathrm{CO}_{2}$ humidified atmosphere. After $48 \mathrm{~h}$ the cells were washed three times with serum-free RPMI 1640 medium and incubated for 1 or $3 \mathrm{~h}$ in the presence of $10^{-14}-10^{-7}$ M AII (Sigma) alone or with different concentrations $10^{14}-10^{-4} \mathrm{M}$ ) of losartan (DuPont de Nemours \& Co., Wilmington, DE). The AII and losartan solutions were prepared in serum-free RPMI 1640 medium. Control cultures were incubated with serum-free RPMI1640 medium.

Opsonized zymosan - Twenty milligrams of zymosan A (Sigma) dissolved in $1 \mathrm{ml}$ of PBS (phosphate-buffered saline, $\mathrm{pH}$ 7.4) were added to $3 \mathrm{ml}$ of pooled normal mouse serum and incubated for $15 \mathrm{~min}$ at $37^{\circ} \mathrm{C}$ with mixing. The particles were washed three times with PBS and resuspended in the same solution for the phagocytic assays.

Phagocytic assay - Macrophage monolayers were obtained as described above and the coverslips were washed with HBSS. Opsonized zymosan particles were added to the monolayers in a 5:1 (particle: macrophage) ratio and the coverslips incubated at $37^{\circ} \mathrm{C}$ in a $5 \% \mathrm{CO}_{2}$ humidified atmosphere. After $30 \mathrm{~min}$, the coverslips were washed with HBSS, fixed in methanol, and stained with Giemsa. After drying, the coverslips were mounted on glass slides and examined microscopically. The percentage of cells with ingested particles was multiplied by the average number of particles per macrophage to calculate phagocytic index. At least 100 macrophages were counted per coverslip.

Dimethylthiazoldiphenyltetrazolium bromide (MTT) assay - The tetrazolium reduction assay was done as described by Denizot and Lang (1986). Briefly, macrophages were incubated for $4 \mathrm{~h}$ with $1 \mathrm{ml}$ of serum-free medium containing $2 \mathrm{mg}$ of MTT/ml (Sigma). The culture medium was removed and the blue formazan product obtained was solubilized in $1 \mathrm{ml}$ of ethanol with shaking for $15 \mathrm{~min}$ on a microtiter plate shaker. The resulting absorbance was measured at $570 \mathrm{~nm}$.

Nucleic acid content - The number of cells in control and treated wells was estimated from their total nucleic acid content according to Cingi et al. (1991). The cells were washed twice with cold PBS and a soluble nucleotide pool was extracted with cold ethanol. The cells monolayers were then dissolved in $0.5 \mathrm{M} \mathrm{NaOH}$ for $1 \mathrm{~h}$ at $37^{\circ} \mathrm{C}$, and the absorbance of the lysate was used as an index of the number of cells. The results were expressed as a percentage of the absorbance at $260 \mathrm{~nm}$ obtained for the controls.

Superoxide anion production - Superoxide production by the macrophages was measured by the reduction of ferricytochrome C (Sigma) as described by Pick and Mizel (1981). Peritoneal cells ( 2 x 105 cells/well) were incubated with reaction solution containing $80 \mu \mathrm{M}$ ferricytochrome $\mathrm{C}$ with zymosan particles in a 5:1 (particle: macrophage) ratio in HBSS. The amount of ferricytochrome $\mathrm{C}$ reduced by superoxide was measured spectrophotometrically at $550 \mathrm{~nm}$. Wells containing medium and ferricytochrome $\mathrm{C}$ only were used as controls.
The total superoxide anion production was calculated using the formula:

Superoxide (nmoles) $=\mathrm{A}_{550} \mathrm{x}$ [volume of incubation mixture (ml)] x 47.4 (Absolom 1986), where $\mathrm{A}_{550}$, is the peak height or maximum absorbance at $550 \mathrm{~nm}$. Superoxide generation was calculated by assuming that a change in absorbance of 1.0 at $550 \mathrm{~nm}$ corresponded to the presence of $47.4 \mathrm{nmol}$ of superoxide. The extinction coefficient for ferricytochrome $\mathrm{C}$ at $550 \mathrm{~nm}$ was considered to be $21,000 \mathrm{M}^{-1} \cdot \mathrm{cm}^{-1}$.

Preliminary experiments showed that superoxide production by peritoneal cells was completely inhibited by the presence of superoxide desmutase. After the removal of non-adherent cells, the macrophages were covered with $1 \mathrm{ml}$ per well of $1 \mathrm{~N} \mathrm{NaOH}$ and incubated overnight at $37^{\circ} \mathrm{C}$ in a humidified incubator. The following day, the $\mathrm{NaOH}$ digest from all wells was pooled and the protein content was determined by the method of Lowry et al. (1951), using bovine serum albumin as standard. The mean protein content $(\mathrm{mg})$ per well determined in this assay was used to express the superoxide production by the cells, and was expressed as nmoles of superoxide produced per mg of protein per hour.

Immunofluorescence staining - Coverslips with macrophage monolayers were fixed in methanol $\left(20^{\circ} \mathrm{C}\right)$ for $1 \mathrm{~h}$. The cells were washed with cold PBS and non-specific binding sites were blocked with milk (3\%) for $1 \mathrm{~h}$ at room temperature. After extensive washing, the cells were incubated overnight $\left(4^{\circ} \mathrm{C}\right)$ with anti-AT ${ }_{1}$ rabbit $\operatorname{IgG}$ (Santa Cruz) or anti- $\mathrm{AT}_{2}$ goat $\operatorname{IgG}$ (Santa Cruz) at a dilution of 1:50. The cells were then washed with PBS and incubated for $2 \mathrm{~h}$ at room temperature with anti-rabbit IgG FITC $(1: 100)$ and anti-goat IgG FITC (1:200). The coverslips were mounted with antifading Vectashield media. The immunofluorescence staining was examined in a Bio-Rad scaning laser confocal microscope equipped with an Axovert 100 microscope (Boer-Lima et al. 2002).

Statistical analysis - Where appropriate, the results were expressed as the mean \pm SEM. Statistical significance was assessed by ANOVA for repeated measurements followed by the Tukey post-hoc test to determine the extent of the differences using the SAS (Statistical Analysis System, version 6.12). A significance level of $5 \%$ was chosen.

\section{RESULTS}

Phagocytic assay - The effect of AII on the phagocytic activity of macrophages was evaluated over the concentration of $10^{-14}$ to $10^{-4} \mathrm{M}$. Exposure to $10^{-13} \mathrm{M}$ and $10^{-12}$ M AII significantly potentiated $(\mathrm{p}<0.05)$ zymosaninduced phagocytosis after 1 and at $10^{-12}$ M AII after $3 \mathrm{~h}$ in a concentration-dependent fashion (Fig. 1). Fig. 2 shows that losartan, a AII receptor antagonist, blocked the stimulatory effect of $10^{-12} \mathrm{M}$ AII on phagocytosis up to $10^{-14}$ M AII concentration tested, with complete inhibition occurring at $10^{-6} \mathrm{M}$ losartan ( $<0.001$ ) (Fig. 1C). When the incubation time was increased to $3 \mathrm{~h}$, losartan alone inhibited phagocytosis at concentrations ranging from $10^{-12} \mathrm{M}$ to $10^{-4} \mathrm{M}$. Similar results were observed in the presence of $10^{-12} \mathrm{M}$ AII, with a major effect at $10^{-6} \mathrm{M}$ of $\operatorname{losartan}(\mathrm{p}<0.001)$ (Fig. 1D). 

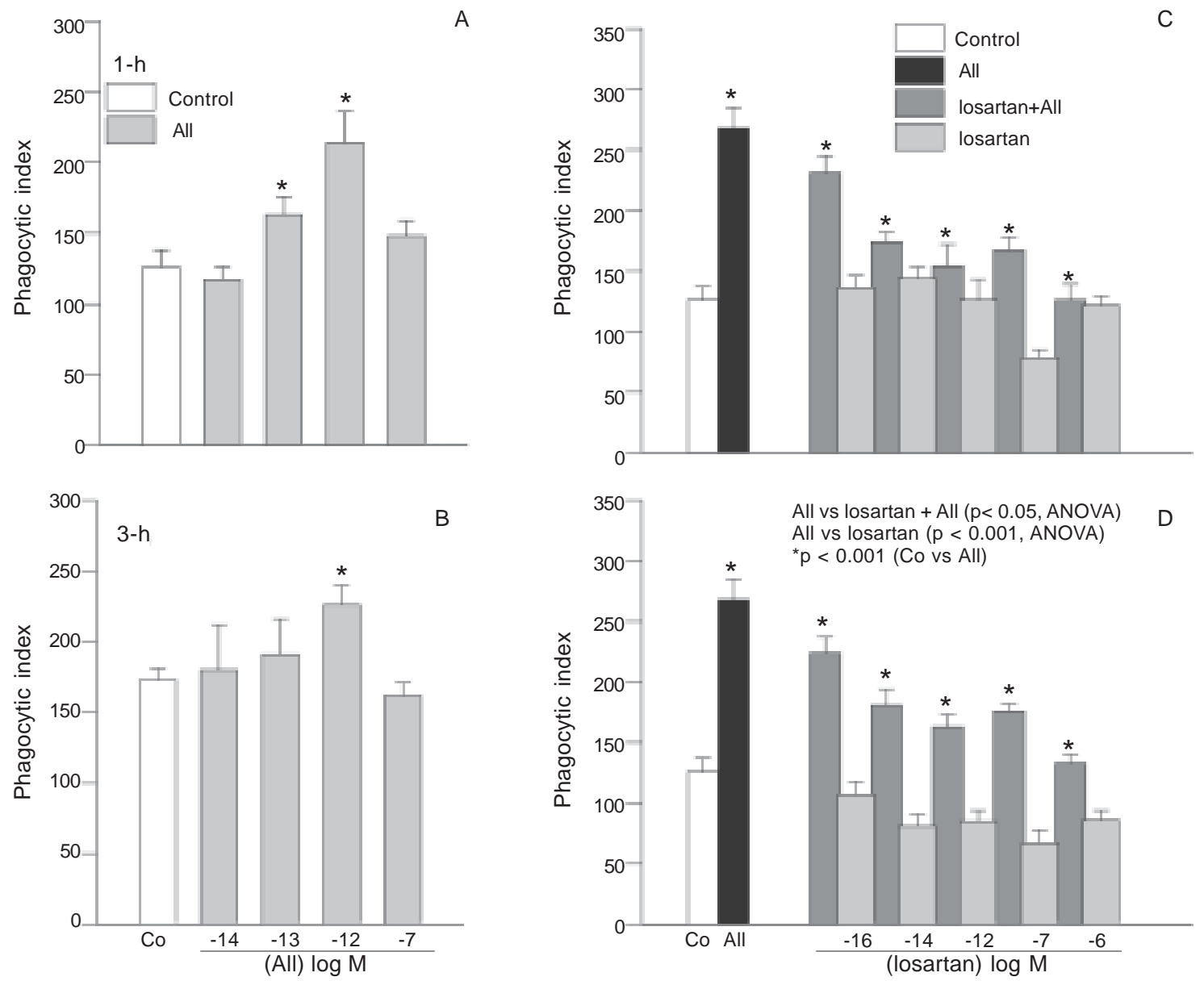

Fig. 1: dose-dependent effect of angiotensin II and/or losartan on the phagocyte activity of peritoneal macrophages. Peritoneal macrophages were exposed in vitro to various concentrations of AII $(n=9)$, losartan and AII $\left(10^{-12} \mathrm{M}, \mathrm{n}=9\right)+\operatorname{losartan}$ for $1 \mathrm{~h}(\mathrm{~A}$ and C, $\mathrm{n}=9$ for each experimental group) or $3 \mathrm{~h}(\mathrm{D}, \mathrm{n}=9)$, and then incubated with zymosan solution for 30 min to determine phagocytic activity. Control cells (Co) were incubated with Roswell Park Memorial Institute (RPMI-1640) medium alone. Statistical significance was assessed by ANOVA for repeated measurements followed by the Tukey post-hoc test to determine the extent of the differences. The data are expressed as means \pm SEM. Two hundred cells were counted per sample.

Cytotoxicity assays - To assess whether the inhibitory effect of losartan on macrophage phagocytic activity was due to the blockade of $\mathrm{AT}_{1}$ receptors, citotoxicity assays were done using the same losartan concentrations as described in the experiments above. No toxic effect was observed when macrophages were incubated with losartan at any of the concentrations tested (Fig. 2). Surprisingly, however, an increase in the nucleic acid content was observed after a $1 \mathrm{~h}$ incubation with $10^{-4} \mathrm{M}$ losartan (Fig. 2A).

Superoxide anion production - The concentration of AII $\left(10^{-12} \mathrm{M}\right)$ that stimulated phagocytosis and this of losartan $\left(10^{-6} \mathrm{M}\right)$, which inhibited phagocytosis, did not significantly influence the superoxide production by macrophages, even after a $3 \mathrm{~h}$ exposure to the drugs (Fig. 2C).

Immunofluorescense - Immunohistochemistry gave a positive reaction for $\mathrm{AT}_{1}$ and $\mathrm{AT}_{2}$ receptors. Pretreating the cells with $10^{-12} \mathrm{M}$ AII increased the intensity of $\mathrm{AT}_{1}$ receptor staining (Fig. 3B). In contrast treatment with $10^{-6} \mathrm{M}$ losartan or with AII + losartan decreased the num- ber of receptors stained (Fig. 3C, D). Similar results were observed with $\mathrm{AT}_{2}$ receptors when the cells were treated with $10^{-12}$ M AII (Fig. 3F).

\section{DISCUSSION}

Components of the RAS are present in isolated liver granulomas associated with murine schistosomiasis, and granuloma macrophages have receptors for AII. These observations, along with other evidence (Iwai et al. 1996), suggest that angiotensin II has a role in immunoregulation. Since AII can stimulate actin-myosin interactions and since macrophages have contractile proteins, the ability of AII to alter the phagocytic activity of granuloma macrophages was examined (Weinstock \& Blum 1987, Iwai et al. 1996, Nickening et al. 1997, Lamperter et al. 1998). At concentrations, which saturate the AII receptors, AII enhanced the phagocytic activity of opsonized and unopsonized sheep red blood cells (RBC). Using a DNase inhibitory assay, similar concentrations of AII were found to intracellular actin polymerization. Cytochalasin B, which 

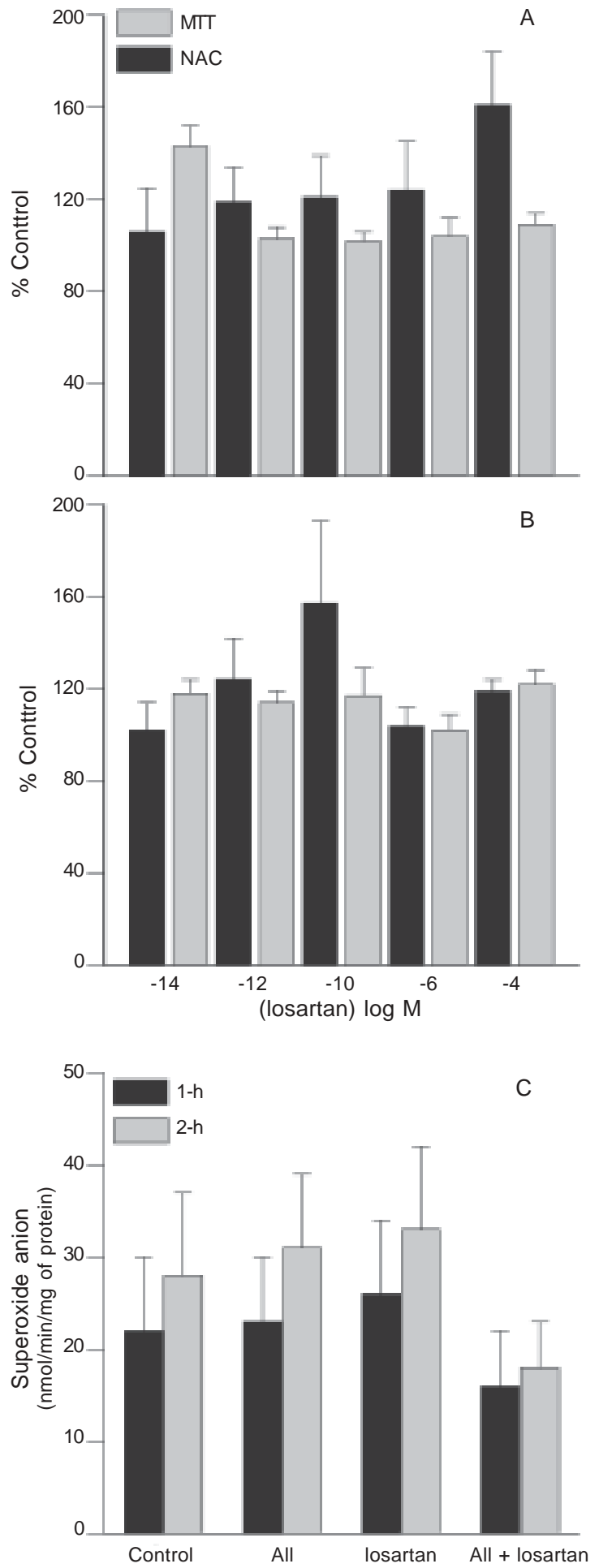

Fig. 2: macrophage viability evaluated by the nucleic acid content (NAC) and MTT (dimethylthiazoldiphenyltetrazolium bromide) reduction assay, and superoxide anion release by peritoneal macrophages (C) after treatment with AII $\left(10^{-12} \mathrm{M}, \mathrm{n}=8\right)$, losartan $\left(10^{-6} \mathrm{M}, \mathrm{n}=8\right)$ and angiotensin II + losartan $(\mathrm{n}=8$ for each time $)$ for $1 \mathrm{~h}(\mathrm{~A})$ or $3 \mathrm{~h}$ (B). The data are reported as the mean \pm SEM of two independent experiments each run in quadruplicate. Statistical significance was assessed by ANOVA test for repeated measurements. A P value $\leq 0.05$ was considered to indicate statistical significance. The data were expressed as a percentage of the corresponding control value. impedes actin filament interactions, inhibited AII-stimulated phagocytosis AII analogs with little agonist activity blocked AII-stimulated actin polymerization and the phagocytosis of non-opsonized RBC and of RBC opsonized with IgG. These data support the contention that AII binds to AII receptors on macrophages and stimulates phagocytosis possibly through the polymerization of intracellular actin. AII of the components of the RAS, except for chymase, have been demonstrated in macrophages (Okamura et al. 1999). AII is involved in rosette formation and in the phagocytosis associated with the contractile elements of the cell, thereby affecting the cytoskeleton (Dezso \& Fóris 1981, Fóris et al. 1983, Weinstock \& Blum 1987, Dezso et al. 1988). Our results are consistent with these data and suggest that the RAS may have an important function in the phagocytic activity of macrophages. The concentration response curve for angiotensin II induced phagocytosis was bimodal, with the greatest stimulation at $10^{-13} \mathrm{M}$ and $10^{-12} \mathrm{M}$ AII concentrations tested.

To determine whether this stimulation occurred via $\mathrm{AT}_{1}$ receptors, the cells were incubated with the $\mathrm{AT}_{1}$ antagonist losartan prior to the determination of phagocytosis. A decrease in phagocytic activity was observed after a $1 \mathrm{~h}$ incubation with $10^{-6} \mathrm{M}$ losartan. When the cells were incubated with different concentrations of losartan in the presence of $10^{-12} \mathrm{M}$ AII there was a decrease in the phagocytic index, thus demonstrating the blockade of $\mathrm{AT}_{1}$ receptors and their involvement in phagocytosis. When the incubation was increased to $3 \mathrm{~h}$, losartan alone inhibited phagocytosis in the concentration range of $10^{-12}$ to $10^{-6} \mathrm{M}$, while in the presence of $10^{-12} \mathrm{M}$ AII, concentrations up to $10^{-14} \mathrm{M}$ of losartan tested also effectively prevented AII-induced increases in phagocytic function. This inhibitory action of losartan was not due to cytotoxicity since losartan did not affect cell viability as assessed by the MTT reduction and nucleic acid content. These results indicate that the binding of $\mathrm{AII}$ to $\mathrm{AT}_{1}$ receptors is essential for the activation of phagocytosis in macrophages.

In addition of phagocytic activity, the effect of AII and losartan on the production of superoxide anions was investigated using ferricytochrome $\mathrm{C}$ reduction. Mesangial cells exposed to AII $\left(10^{-7} \mathrm{M}\right.$ to $\left.10^{-5} \mathrm{M}\right)$ show a significant increase in superoxide production mediated by $\mathrm{AT}_{1}$ receptors (Jaimes et al. 1998). In peritoneal macrophages, the concentrations of AII and losartan which stimulated and inhibited phagocytosis, respectively, did not influence superoxide production, perhaps because the concentrations tested were not optimal.

Immuonofluorescense microscopy identified $\mathrm{AT}_{1}$ and $\mathrm{AT}_{2}$ receptors on peritoneal macrophages treating the cells with AII and losartan changed the immunoreactivity with $\mathrm{AII}$ increasing the number of $\mathrm{AT}_{1}$ and $\mathrm{AT}_{2}$ receptors, whereas losartan decreased the intensity of the immunofluorescense. Together, these results suggest that AII receptors may modulate murine macrophage activity and phagocytosis is dissociated from free-radical generation.

Perspectives - Our results support the hypothesis that angiotensin can directly modulate peritoneal macrophage function, and may have a therapeutic role as an immunomodulatory agent in modifying the host resistance to infection. 

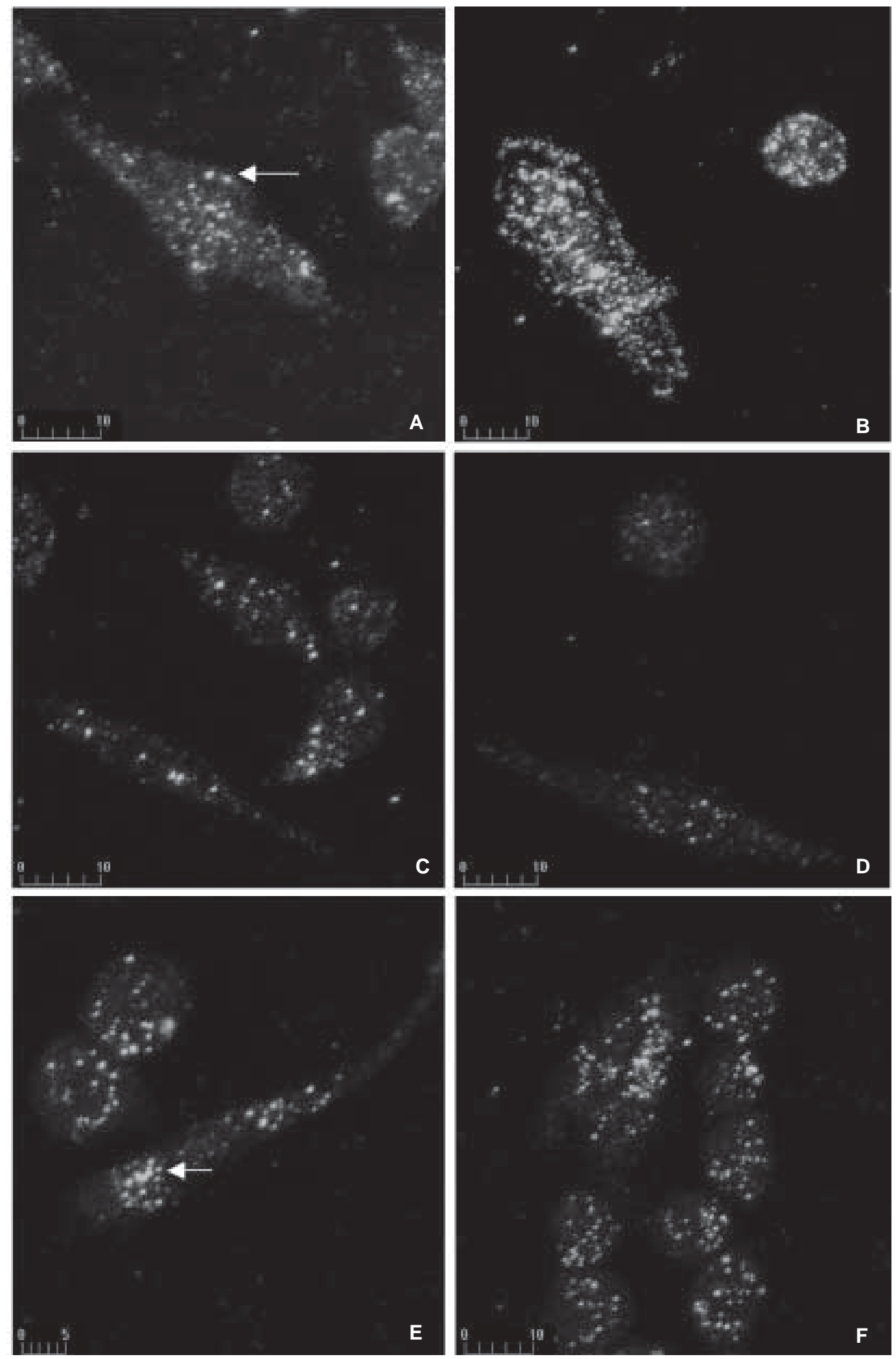

Fig. 3: immunoreactive $\mathrm{AT}_{1}$ receptors in mouse peritoneal macrophages. A: control group; $\mathrm{B}$ : macrophages treated for $1 \mathrm{~h}$ with angiotensin II $\left(10^{-12} \mathrm{M}\right)$; C: macrophages treated for $1 \mathrm{~h}$ with losartan $\left(10^{-6} \mathrm{M}\right)$; D: macrophages treated for $1 \mathrm{~h}$ with AII and losartan. Immunoreactive $\mathrm{AT}_{2}$ receptors in mouse peritoneal macrophages $(\mathrm{E}, \mathrm{F})$; $\mathrm{E}$ : control group; $\mathrm{F}$ : macrophages treated for $1 \mathrm{~h}$ with $\mathrm{AII}$ $\left(10^{-12} \mathrm{M}\right)$. 


\section{ACKNOWLEDGEMENTS}

To Dr Giselle Z Justo for a critical reading of this manuscript.

\section{REFERENCES}

Absolom DR 1986. Basic methods for the study of phagocytes. Meth Enzymol 132: 95-180.

Boer-Lima PA, Gontijo JAR, Cruz-Hofling MA 2002. Bothrops moojeni snake venom-induced renal glomerular changes in rat. Am J Trop Med Hyg 67: 217-222.

Brewster UC, Setaro JF, Perazella MA 2003. The renin-angiotensin-aldosterone system: cardiorenal effects and implications for renal and cardiovascular disease states. Am J Med Sci 326: 15-24

Cingi MR, Angelis I, Fortunati E, Regiani D, Bianchi V, Tiozzo R, Zucco F 1991. Choice and standardization of test protocols in cytotoxity: a multicentre approach. Toxicol Vitro 5: 129-125.

Denizot F, Lang R 1986. Rapid colorimetric assay for cell growth and survival. Modifications to the tetrazolium dye procedure giving improved sensitivity and readability. J Immunol Meth 89: 271-277.

Dezso B, Fóris G 1981. Effect of angiotensin II on the receptor activity of rat macrophages. Immunology 42: 277-283.

Dezso B, Nielsen AH, Pousen K 1988. Identification of renin in resident alveolar macrophages and monocytes. J Cell Sci 91: 155-159.

Fóris G, Dezso B, Medgyesi GA, Fust G 1983. Effect of angiotensin II on macrophage functions. Immunology 48: 529535.

Iwai N, Inagami T, Ohmichi N, Kinoshita M 1996. Renin is expressed in rat macrophage/ monocyte cells. Hypertension 27: 399-403.

Jaimes EA, Galceran JM, Raij L 1998. Angiotensin II induces superoxide anion production by mesangial cells. Kidney Int 54: 775-784.

Kumar KV, Das UN 1993. Are free radicals involved in the pathobiology of human essential hypertension? Free Rad Res Comm 19: 59-66.

Lamparter S, Lothar K, Scharader M, Ziegler R, Pfeilschifter J 1998. Effects of angiotensin II on bone cells in vitro. J Cell Physiol 175: 89-98.

Lavoie JL, Sigmund CD 2003. Minireview: overreview of the rennin-angiotensin system - An endocrine and paracrine system. Endocrinology 144: 2179-2183.

Lowry OH, Rosebrough NJ, Farr AL, Randall RJ 1951. Protein measurement with the Folin-Phenol reagent. J Biol Chem
193: 265-275.

Matsusaka T, Ichikawa I 1997. Biological functions of angiotensin and its receptors. Ann Rev Physiol 59: 395-412.

Nickening G, Geisen G, Vetter H, Sachinidis A 1997. Characterization of angiotensin receptors on human skin fibroblasts. J Mol Med 75: 217-222.

Okamura A, Rakugi H, Ohishi M, Yanagitani Y, Takiuchi S, Moriguchi K, Fennessy PA, Higaki J, Ogihara T 1999. Upregulation of renin-angiotensin system during differentiation of monocytes to macrophages. J Hypertension 17: 537-545.

Pick E, Mizel D 1981. Rapid microassays for the measurement of superoxide and hydrogen peroxide production by macrophages in culture using an automatic enzyme immunoassay reader. J Immunol Meth 46: 211-226.

Prabha PS, Das UN, Koratkar R, Sagar OS, Ramesh G 1990. Free radical generation, lipid peroxidation and essential fatty acids in uncontrolled essential hypertension. Prostaglandins Leuko Essent Fatty Acids 41: 27-33.

Pueyo ME, Arnal JF, Rami J, Michel JB 1998. Angiotensin II stimulates the production of $\mathrm{NO}$ and peroxynitrite in endothelial cells. Am J Physiol 274: C214-C220.

Regitz-Zagrosek V, Neuss M, Holzmeiter J, Warnecke C, Fleck E 1996. Molecular biology of angiotensin receptors and their role in human cardiovascular disease. $\mathrm{J} \mathrm{Mol} \mathrm{Med} \mathrm{74:}$ 233-251.

Scheidegger KJ, Butler S, Witztum JL 1997. Angiotensin II increases macrophage-mediated modification of low-density lipoprotein via a lipoxygenase-dependent pathway. $J$ Biol Chem 272: 21609-21615.

Thomas DW, Hoffman MD 1984. Identification of macrophage receptors for angiotensin: a potential role in antigen uptake for T lymphocyte response? J Immunol 132: 2807-2812.

Weinstock JV, Blum AM 1987. Synthesis of angiotensins by cultured granuloma macrophages in murine schistosomiasis mansoni. Cell Immunol 107: 273-280.

Weinstock JV, Kassab JT 1984. Angiotensin II stimulation of granuloma macrophage phagocytes and actin polymerization in murine schistosomiasis mansoni. Cell Immunol 89: 46-54.

Wolf G, Haberstroh U, Neilson EG 1992. Angiotensin II stimulates the proliferation and biosynthesis of type I collagen in cultured murine mesangeal cells. Am J Pathol 140: 96-107.

Yanagitani Y, Rakugi H, Okamura A, Moriguchi K, Takiuchi S, Ohishi M, Suzuki K, Higari J, Ogihara T 1999. Angiotensin II type 1 receptor-mediated peroxide production in human macrophages. Hypertension 33: 335-339. 